\title{
HUBUNGAN ANTARA HOTSPOT DAN KEBAKARAN TERHADAP TIMBULNYA PENYAKIT INFEKSI SALURAN PERNAPASAN AKUT (ISPA) DI KABUPATEN KUBU RAYA, KALIMANTAN BARAT
}

\author{
The Correlation between Distribution of Hotspots and Forest and Land Fire with the Onset of Acute \\ Respiratory Infections (ARI) in Kubu Raya District, West Kalimantan
}

\author{
Bambang Hero Saharjo $^{1^{*}}$ dan Denada Ramadhania ${ }^{1}$
}

(Diterima Maret 2018/Disetujui November 2019)

\begin{abstract}
ABSTRAK
Kalimantan is one of the Islands that often have forest and land fires where almost the entire province of Borneo ever burning. This negatively impact to the environment and human beings. This study aims to measure the correlation between distribution of hotspots as a sign of forest and land fire with the onset of Acute Respiratory Infections. In this study, was conducted a descriptive analysis on the improvement of the health impact which is limited to Acute Respiratory Infections based on age and gender. The highest amount of hotspots is in subdistrict of Sungai Raya about 144 hotspots, whereas the lowest amount of hotspots is in the Sub District of Sungai Kakap 8 hotspots. Sub-district which have the widest acreage burned was Batu Ampar sub-district which reach 5881.46 hectares, whereas the slightest acreage burned was in subdistrict of Sungai Kakap, about 4.18 hectares have been burned. The largest amount of sufferers of ISPA patients were in district of Sungai Raya, about 11302 patients, whereas the lowest amount of sufferers of Acute Respiratory Infections patients were in the Teluk Pakedai Sub-district that is about 1129 sufferers of Acute Respiratory Infections patients. Result of statistical analysis showed the amount of sufferers patients with the amount of Hotspots has positive correlation $(r=0.507)$. The value of the correlation between the amount of Acute Respiratory Infections patients with burning land area also has a positive correlation $(r=0.377)$. As for the correlation between the amount of hotspots with acreage burned has a positive correlation $(r=0.938)$. The result of $R$ square trial obtained regression equation $Y=$ $2240+19.3 X$ which is not relevant to be used in determining the correlation between the increase of Acute Respiratory Infections patients with amount of hotspots. The most Patient of Acute Respiratory Infections in Kubu Raya found on classes age 1-4 years old and based on the type of gender, the difference in the amount of patients between men and women do not indicate significant differences.
\end{abstract}

Key words: Acute Respiratory Infections (ARI), Forest and Land Fires, Hotspot, West Kalimantan

\section{PENDAHULUAN}

Hutan merupakan sumber daya alam yang sangat potensial untuk dimanfaatkan. Hutan mempunyai berbagai fungsi antara lain sebagai penghasil kayu, sumber plasma nutfah, ekosistem, habitat flora dan fauna, serta sebagai pengatur tata air dan pengawetan tanah. Fungsi tersebut sangat penting bagi kehidupan manusia, sehingga perlu dijaga akan kelestariannya dari ancaman dan gangguan yang menyebabkan berkurangnya atau hilangnya fungsi tersebut. Salah satu bentuk ancaman dan gangguannya adalah kebakaran hutan dan lahan (Purbawaseso 2004).

Kebakaran hutan merupakan suatu peristiwa terbakarnya vegetasi yang penjalarannya bebas serta mengkonsumsi bahan bakar alam dari hutan. Proses pembakaran bahan bakar dari hutan akan menghasilkan panas serta senyawa lainnya seperti karbon monoksida,

\footnotetext{
${ }^{1}$ Departemen Silvikultur Fakultas Kehutanan Institut

Pertanian Bogor

* Penulis korespondensi:

E-mail: bhherosaharjo@gmail.com
}

karbon dioksida dan unsur unsur lain dalam bentuk gas, cair atau padatan (partikel) yang akan menjadi kabut asap dari fase smoldering. Bahkan tidak jarang asap yang muncul merupakan asap yang tebal atau pekat. Asap inilah yang merupakan dampak paling mengganggu bagi kesehatan manusia. Asap yang tebal merupakan polusi udara. Asap dari kebakaran hutan mengandung bahan bahan kimia antara lain karbon dioksida, uap air, karbon monoksida,bahan partikel, hidrokarbon, nitrogen dan sulfur dioksida, radikal bebas, dan fraksi anorganik lainnya (Syaufina 2008). Menurut para pakar kesehatan, polusi udara yang melebihi ambang batasnya jelas akan menimbulkan penyakit terhadap manusia. Penyakit-penyakit yang sering timbul akibat oleh asap adalah infeksi saluran pernapasan, asma bronkial, bronkitis, pneumonia (radang paru), iritasi mata, dan kulit. Infeksi saluran pernapasan akut merupakan penyakit yang banyak dialami oleh masyarakat karena penyakit tersebut diakibatkan oleh pencemaran udara karena pertahanan saluran pernapasan terhadap bakteri atau virus menjadi lemah (Purbawaseso 2004).

Pulau Kalimantan merupakan salah satu pulau yang sering terjadi kebakaran hutan dan lahan. Provinsi 
Kalimantan Barat memiliki kawasan gambut terluas ke dua setelah Kalimantan Timur, yaitu sekitar 1.73 juta hektar. Salah satu kabupaten yang memiliki lahan gambut terluas di Provinsi Kalimantan Barat yaitu Kabupaten Kubu Raya. Kebakaran hutan dan lahan di Kabupaten Kubu Raya umumnya terjadi di lahan gambut yang menimbulkan asap yang pekat dan tebal. Asap tersebut dapat menimbulkan berbagai penyakit, seperti infeksi saluran pernafasan dan lainnya.

Provinsi Kalimantan Barat adalah salah satu wilayah dengan kemunculan titik panas terbanyak selain Provinsi Riau, Jambi, Sumatera Selatan, Kalimantan selatan. Sistem informasi deteksi dini dapat menggunakan informasi titik panas (hotspot) yang didapatkan dari penginderaan jauh melalui satelit MODIS sehingga dapat diketahui jumlah hotspot dan luasan areal yang terbakar. Dengan informasi tersebut dapat menduga penyebaran luasan daerah yang terkena dampak kebakaran seperti timbulnya penyakit Infeksi Saluran Pernapasan Akut (ISPA). Penelitian ini bertujuan untuk memberikan informasi tentang hubungan antara jumlah hotspot dengan timbulnya penyakit Infeksi Saluran Pernapasan Akut (ISPA) agar dapat mencegah terjadinya penyebaran penyakit Infeksi Saluran Pernapasan Akut (ISPA) yang menyebar akibat asap.

\section{METODE PENELITIAN}

\section{Waktu dan Lokasi Penelitian}

Penelitian ini dilaksanakan pada bulan Januari sampai dengan Juni 2016 yang dilakukan di Kabupaten Kubu Raya Provinsi Kalimantan Barat dan Laboratorium Kebakaran Hutan dan Lahan Fakultas Kehutanan, Institut Pertanian Bogor.

\section{Alat dan Bahan}

Alat yang digunakan dalam penelitian ini adalah komputer dengan beberapa perangkat lunak yaitu Microsoft Excel, ArcMap 10.1, Minitab 16 Statistic Software, kalkulator, dan alat tulis. Bahan yang digunakan dalam penelitian ini adalah data jumlah penderita penyakit Infeksi Saluran Pernapasan (ISPA) dari Dinas Kesehatan Kabupaten Kubu Raya, Puskesmas Kecamatan Sungai Raya, dan Puskesmas Kecamatan Rasau Jaya pada tahun 2015; data jumlah hotspot tahun 2015 Kabupaten Kubu Raya di download dari Web Earth Data NASA (https://earthdata.nasa.gov); data unsur iklim bulanan pada tahun 2015 dari Stasiun Klimatologi Siantan Pontianak Kalimantan Barat; data wilayah kehutanan dari Dinas Kehutanan dan Perkebunan Kabupaten Kubu Raya; data kependudukan (Kubu Raya dalam Angka) dari BPS Kabupaten Kubu Raya; dan data luas lahan terbakar di Kabupaten Kubu Raya dari Lembaga Penerbangan dan Antariksa Nasional (LAPAN).

\section{Rancangan Penelitian}

Penelitian ini mengukur hubungan antara peningkatan sebaran titik panas (hotspot) sebagai penunjuk adanya kebakaran hutan dan lahan, luas lahan terbakar dengan peningkatan kejadian penyakit Infeksi Saluran Pernapasan (ISPA) di beberapa kecamatan di Kubu Raya pada tahun 2015.

Selanjutnya akan dilakukan penelitian deskriptif untuk memperoleh gambaran mengenai peningkatan dampak kesehatan yang terbatas pada penyakit Infeksi Saluran Pernapasan Akut (ISPA) dilihat dari kelas umur dan jenis kelamin.

\section{Analisis Data}

\section{Uji Korelasi}

Studi korelasi prinsipnya adalah dua variabel $(\mathrm{X}, \mathrm{Y})$ diukur pada tiap-tiap unit observasi. Kekuatan hubungan linier antara variabel $\mathrm{X}$ dan variabel $\mathrm{Y}$ dihitung dalam koefisien yang disebut koefisien korelasi (r). Koefisien korelasi mengukur berapa besar perubahan setiap unit variabel diikuti oleh perubahan setiap unit paparan, atau sebaliknya (Murti 1997 diacu dalam Tristiyenny 2003) Nilai korelasi (r) berkisar dari 0 sampai dengan 1 atau bila disertai arahnya nilainya antara -1 sampai dengan +1 (Walpole 1988). Colton dalam Tristiyenny (2003) menyatakan kekuatan hubungan antara dua variabel secara kualitatif dapat dibagi dalam 4 area, yaitu:

$$
\begin{array}{ll}
\text { 1. } & r=0.00-0.25 \text { tidak ada hubungan } \\
\text { 2. } & r=0.26-0.50 \text { hubungan sedang } \\
\text { 3. } & r=0.52-0.75 \text { hubungan kuat } \\
\text { 4. } r= & 0.76-1.00 \text { hubungan sangat kuat/ } \\
& \text { sempurna }
\end{array}
$$

\section{Uji Regresi}

Bentuk hubungan antara dua variabel menggunakan analisis regresi. Regresi linier bertujuan untuk membuat sebuah persamaan untuk memperkirakan nilai suatu variabel melalui variabel lain. Menurut Mattjik dan Summerajaya (2013) untuk memprediksi penelitian ini dapat digunakan persamaan garis dengan regresi linier yang dituliskan dalam bentuk:

$$
\mathrm{Y}=\mathrm{a}+\mathrm{bX}
$$

keterangan :

$\mathrm{Y}=$ variabel dependen (peubah tak bebas)

$\mathrm{X}=$ variable independen (peubah bebas)

$\mathrm{a}=$ parameter intersep

$\mathrm{b}=$ koefisien regresi (slop)

Ukuran yang terpenting dalam analisis regresi adalah koefisien determinasi $\left(\mathrm{R}^{2}\right)$, dimana nilai tersebut berguna untuk mengetahui seberapa besar variabel dependen (Y) dapat dijelaskan oleh variabel independen (X). Besarnya nilai $\mathrm{R}^{2}$ antara $0-1$ atau $0 \%$ sampai dengan $100 \%$. Model persamaan yang diperoleh menghasilkan nilai koefisien determinasi yang rendah $\left(\mathrm{R}^{2}<50 \%\right)$, maka model persamaan yang dihasilkan tidak relevan untuk diterapkan dalam perhitungan. Nilai ini semakin besar (mendekati 1), maka prediksi yang dibuat semakin akurat (Sarwono 2013). 


\section{KONDISI UMUM LOKASI PENELITIAN}

\section{Letak Geografis}

Secara geografis, Kabupaten Kubu Raya berada disisi Barat Daya Provinsi Kalimantan Barat atau berada pada posisi $0^{\circ} 13$ '40.83' sampai dengan $1^{\circ} 00$ '53.09', Lintang Selatan dan $109^{\circ}$ 02'19.32', Bujur Timur sampai dengan $109^{\circ}$ 58'32.16' Bujur Timur. Sedangkan secara administratif, batas wilayah Kabupaten Kubu Raya adalah sebagai berikut:

1. Utara: berbatasan dengan kota Pontianak, Kabupaten Pontianak dan Kabupaten Landak.

2. Selatan: berbatasan dengan Kabupaten Kayong Utara.

3. Barat : berbatasan dengan Laut Natuna.

4. Timur: berbatasan dengan Kabupaten Ketapang dan Kabupaten Sanggau.

Kabupaten Kubu Raya merupakan hasil pemekaran Kabupaten Pontianak yang dibentuk berdasarkan Undang-Undang Nomor : 35 Tahun 2007 tentang Pembentukan Kabupaten Kubu Raya di Provinsi Kalimantan Barat. Luas wilayah Kabupaten Kubu Raya

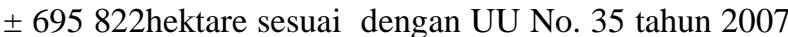
terdiri dari 9 (sembilan) kecamatan, sedangkan berdasarkan hasil perhitungan peta digital 881322.41 Ha.

\section{Curah Hujan dan Keadaan Angin}

Curah hujan dipengaruhi oleh berbagai faktor diantaranya adalah iklim, keadaan geografi dan perputaran atau pertemuan arus udara. Kecamatan yang memiliki curah hujan tertinggi di Kabupaten Kubu Raya pada tahun 2015 adalah Kecamatan Sungai Raya dan Rasau Jaya yaitu sebesar $3470 \mathrm{~mm} / \operatorname{tahun}$ dan 3033 $\mathrm{mm} / \mathrm{tahun}$. Curah hujan terendah terjadi pada Kecamatan Terentang yaitu 2298 mm/tahun. Arah angin di Kabupaten Kuburaya cenderung bergerak ke arah barat dan Selatan.

\section{Penduduk}

Penduduk dari satu sisi merupakan sumber utama dalam proses pembangunan karena bagaimanapun penduduklah yang sangat aktif dalam proses pembangunan tersebut. Kabupaten Kubu Raya pada tahun 2014 tercatat sebesar 538815 jiwa. Jika dibagi dengan luas wilayah Kubu Raya yang cukup luas yakni $6985.24 \mathrm{Km}^{2}$, sehingga kepadatan penduduk tercatat sebesar 77 jiwa per $\mathrm{Km}^{2}$. Jumlah penduduk laki-laki di Kabupaten Kubu Raya lebih banyak daripada jumlah penduduk perempuan.

\section{HASIL DAN PEMBAHASAN}

\section{Sebaran Hotspot Kabupaten Kubu Raya}

Hotspot (titik panas) adalah indikator kebakaran hutan dan lahan yang mendeteksi suatu lokasi yang memiliki suhu relatif lebih tinggi dibandingkan dengan suhu disekitarnya (Permenhut Nomor P.12/MenhutII/2009). Tahun 2015, Kabupaten Kubu Raya mempunyai hotspot sebanyak 468 buah yang tersebar di 9 kecamatan. Kecamatan Sungai Raya merupakan kecamatan yang memiliki jumlah hotspot (titik panas) yang paling banyak yaitu berjumlah 144 buah. Sedangkan Kecamatan Sungai Kakap memiliki hotspot (titik panas) paling sedikit yaitu 6 buah. Kecamatan Sungai Raya merupakan kecamatan yang memiliki wilayah terluas setelah Kecamatan Batu Ampar dan Kecamatan Kubu yaitu 129565 hektare dan Kecamatan Sungai Raya juga memiliki jumlah penduduk terbanyak yaitu sekitar 202453 jiwa pada tahun 2014. Luas wilayah yang cukup luas dan jumlah penduduk yang padat, Kecamatan Sungai Raya memiliki jumlah hotspot terbanyak hal ini dapat dikaitkan dengan kebiasaan atau pekerjaan masyarakat dalam pembukaan lahan untuk perkebunan dan kelapa sawit yang biasanya dilakukan dengan cara membakaran lahan.

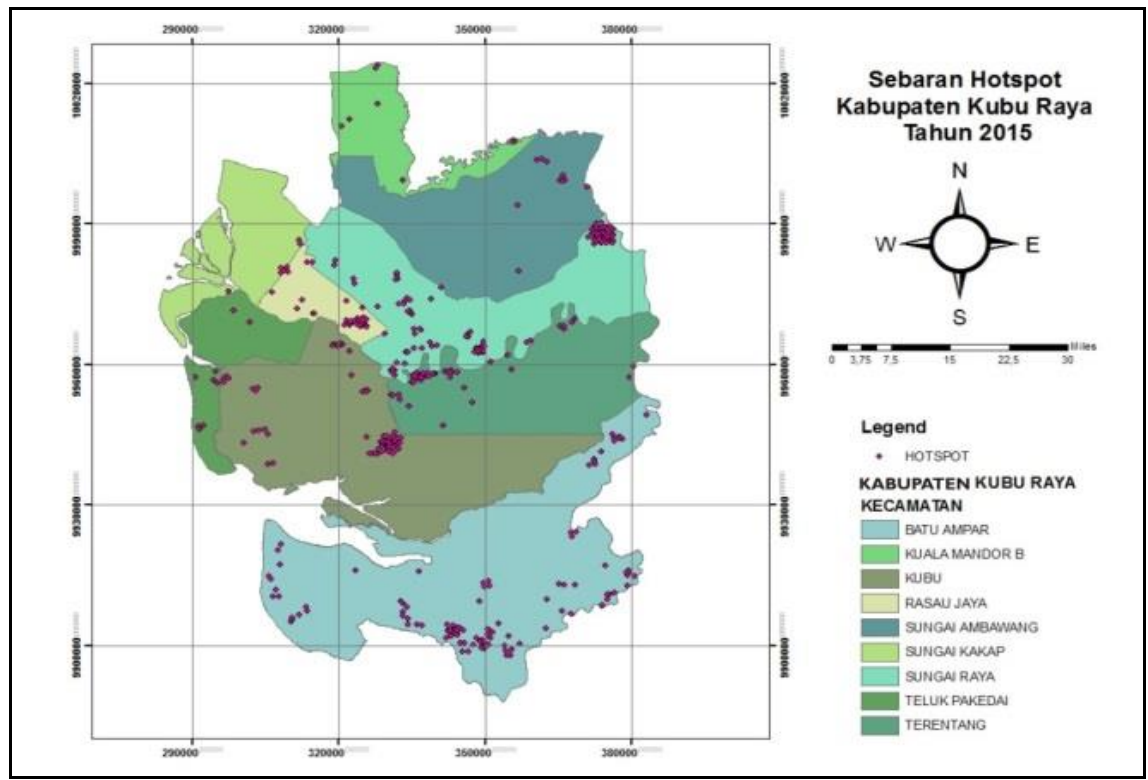

Gambar 1 Peta sebaran hotspot Kabupaten Kubu Raya Tahun 2015 
Pembukaan lahan untuk perkebunan dan kelapa sawit di Kecamatan Sungai Raya banyak dilakukan karena Kecamatan Sungai Raya memiliki lahan gambut yang paling luas yaitu sekitar 32769 hektar. Sementara Kecamatan Sungai Kakap memiliki lahan gambut terkecil yaitu 2704 hektare, hal ini dapat dikaitkan dengan jumlah hotspot di Kecamatan Sungai Kakap yang paling sedikit karena luas lahan gambut yang terbatas maka pemanfaatan lahan oleh masyarakat yang terbatas.

\section{Kebakaran Hutan dan Lahan di Kabupaten Kubu Raya Tahun 2015}

Kabupaten Kubu Raya merupakan Kabupaten yang memiliki luasan gambut terluas diikuti kabupaten Mempawah seluas 32769 hektare. Dapat dilihat pada Gambar 2, Luas areal terbakar hampir seluruhnya berada pada tutupan lahan gambut, yang berarti lahan yang terbakar berada pada areal lahan gambut.

Tabel 1 Luas lahan terbakar Kabupaten Kubu Raya tahun 2015

\begin{tabular}{lrr}
\hline Kecamatan & \multicolumn{1}{c}{$\begin{array}{c}\text { Luas Lahan } \\
\text { terbakar (ha) }\end{array}$} & $\begin{array}{l}\text { Luas gambut } \\
\text { terbakar (ha) }\end{array}$ \\
\hline Sungai & 663.78 & 663.78 \\
Ambawang & 22.29 & 0 \\
Kuala Mandor & 4248.28 & 3980.00 \\
Sungai Raya & 4.18 & 4.18 \\
Sungai Kakap & 618.39 & 618.39 \\
Rasau Jaya & 532.1 & 0 \\
Teluk Pakedai & 2272.85 & 1722.45 \\
Terentang & 1994.56 & 1730.17 \\
Kubu & 5881.46 & 2166.46 \\
Batu Ampar & 16237.89 & 10885.43 \\
\hline Jumlah & &
\end{tabular}

Jumlah luas lahan terbakar di Kabupaten Kubu Raya pada tahun 2015 mencapai luasan sebesar 16237.89 hektare yang terdiri dari 121 kejadian kebakaran. Dapat dilihat dari tabel 1 bahwa kecamatan yang paling banyak terjadinya kebakaran adalah kecamatan Batu Ampar dan Kecamatan Sungai Raya yaitu mencapai angka 5881.46 hektare dan 4248.28 hektar. Sementara luas areal terbakar yang paling sedikit berada di kecamatan Sungai Kakap sebesar 4.18 hektar. Hal tersebut berkaitan dengan kutipan artikel dari Irawan (2015), ribuan hektare hutan gambut dan perkebunan sawit di Kabupaten Kubu Raya, Kalimantan Barat, habis terbakar. Kebakaran berada di lokasi berbeda, di antaranya Batu Ampar dan Sungai Raya yang terpantau melalui patroli udara Badan Nasional Penanggulangan Bencana (BNPB). Berdasarkan titik koordinat yang terekam, kawasan yang terbakar di kecamatan Batu Ampar dan Sungai Raya adalah lahan konsesi perusahaan kebun sawit yang dibiarkan terbakar dan tidak terlihat adanya upaya pemadaman di lokasi yang terbakar tersebut.

Lahan gambut di kabupaten Kubu Raya memiliki tingkat kematangan yang sedang (fibrik/hemik) dimana $1 / 3-2 / 3$ dari bahan asalnya yang sudah terdekomposisi. Luas lahan gambut yang terbakar di kabupaten Kubu Raya pada tahun 2015 mencapai 10885.43 hektare atau $67 \%$ dari total luas lahan terbakar di kabupaten Kubu Raya sebesar 16237.89 hektar. Semakin luas lahan yang terbakar, maka akan menimbulkan asap yang banyak dan menyebar yang menyebabkan kualitas udara yang buruk. Kualitas udara dapat ditunjukkan oleh Indeks Standar Kualitas Udara (ISPU) yang merupakan integrasi dari kandungan beberapa senyawa seperti: PM10, $\mathrm{SO}_{2}, \mathrm{CO}, \mathrm{O}_{3}$, dan $\mathrm{NO}_{2}$. Kualitas udara dikatakan baik jika nilai ISPU kurang dari 100 dan dikatakan dalam kondisi yang berbahaya bila nilai ISPU lebih dari 300 (Saharjo dan Syaufina 2015). Hasil penelitian Gunawan et al. (2011) menjelaskan bahwa asap hasil pembakaran lahan gambut mengandung banyak unsur CO (Karbon Monoksida). Menurut Nasution et al. (2013) Besarnya emisi CO yang dihasilkan dari

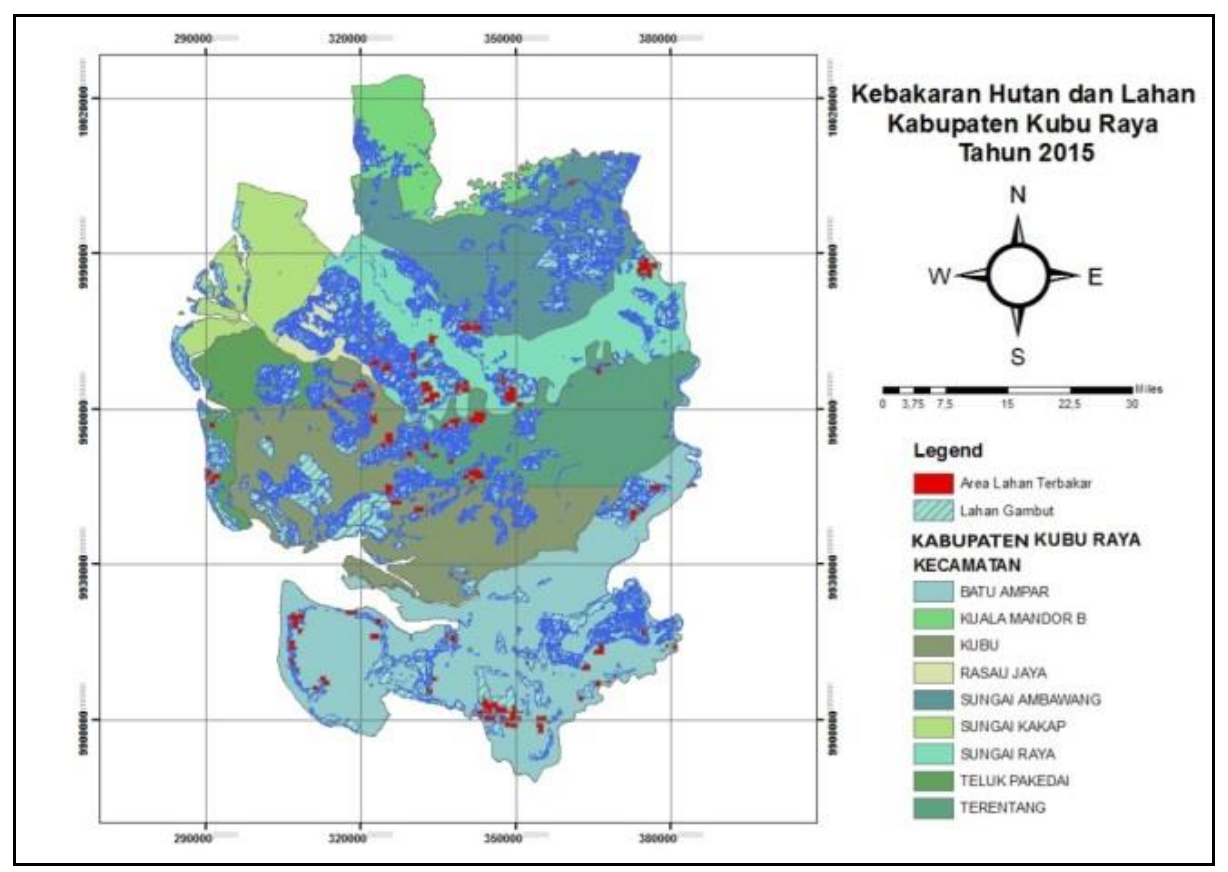


pembakaran lahan gambut sangat dipengaruhi oleh luasnya area yang terbakar.

PM10 bersifat sangat mudah terhirup dan masuk ke dalam paru-paru akibatnya akan mengganggu sistem pernafasan bagian atas maupun bagian bawah (alveoli). Debu yang lebih kecil dari $10 \mu \mathrm{m}$, akan menyebabkan iritasi mata, mengganggu serta menghalangi pandangan mata (Chahaya 2003). Senyawa Sulfurdioksida $\left(\mathrm{SO}_{2}\right)$ menimbulkan efek iritasi pada saluran nafas sehingga menimbulkan gelaja batuk dan sesak nafas. Karbon monoksida $(\mathrm{CO})$ beredar melalui aliran darah dan paru, mengurangi pengiriman oksigen ke jaringan tubuh (anoksia) menimbulkan gejala sesak napas, kebingungan, dan dada terasa berat. Ozon $\left(\mathrm{O}_{3}\right)$ dapat mengiritasi tenggorokan. Nitrogen dioksida $\left(\mathrm{NO}_{2}\right)$ adalah gas yang sangat berbahaya jika terhirup oleh manusia karna dapat menyebabkan gangguan pernapasan (penurunan kapasitas difusi paru-paru) (Faisal, Yunus, Harahap 2012).

\section{Jumlah Pasien ISPA di Kabupaten Kubu Raya Tahun 2015}

Infeksi Saluran Pernapasan Akut (ISPA) adalah gejala penyakit dimana masuknya kuman atau mikroorganisme ke dalam tubuh manusia melalui saluran pernapasan dimulai dari hidung hingga alveolia beserta organ aneksanya seperti sinus-sinus, rongga telinga dan pleura. Jumlah pasien penderita Infeksi Saluran Pernafasan (ISPA) di Kabupaten Kubu Raya pada tahun 2015 dapat dilihat pada tabel 2.

Jumlah penderita ISPA di Kabupaten Kubu Raya dari tahun ke tahun semakin meningkat. Tabel 2 menunjukan jumlah pasien penderita ISPA di Kabupaten Kubu Raya pada tahun 2015 mencapai 35 718 pasien yang tercatat di 19 puskesmas pada 9 kecamatan. Jumlah pasien penderita ISPA terbanyak berada di Kecamatan Sungai Raya yaitu 11302 pasien. Sedangkan jumlah pasien penderita ISPA terendah ada pada Kecamatan Teluk Pakedai yaitu sebanyak 1129 pasien penderita ISPA. Dilihat dari jumlah penduduk, kecamatan Sungai Raya merupakan jumlah penduduk yang terbanyak di Kabupaten Kubu Raya yaitu 102885 jiwa/tahun sedangkan Kecamatan Teluk Pakedai adalah

Tabel 2 Jumlah pasien penderita Infeksi Saluran Pernafasan (ISPA) di Kabupaten Kubu Raya pada tahun 2015

\begin{tabular}{lc}
\hline \multicolumn{1}{c}{ Kecamatan } & Jumlah penderita ISPA \\
\hline Sungai Ambawang & 6420 \\
Kuala Mandor & 1603 \\
Sungai Raya & 11302 \\
Sungai Kakap & 4610 \\
Rasau Jaya & 2360 \\
Teluk Pakedai & 1129 \\
Terentang & 2077 \\
Kubu & 1810 \\
Batu Ampar & 3407 \\
\hline Jumlah & 34718 \\
\hline
\end{tabular}

jumlah penduduk terendah setelah Kecamatan Terentang yaitu $19900 \mathrm{jiwa} / \mathrm{tahun}$. Hal tersebut dapat dikaitkan dengan jumlah penduduk yang tinggi akan menyebabkan jumlah penderita ISPA yang tinggi pula.

\section{Hubungan Hotspot dengan Timbulnya Penyakit ISPA}

Jumlah hotspot yang terdapat di Kabupaten Kubu Raya pada tahun 2015 berjumlah 468 buah yang tersebar di 9 kecamatan. Luas areal terbakar pada Kabupaten Kubu Raya tahun 2015 mencapai 16238 hektare dengan masing-masing kecamatan memiliki luas terbakar yang berbeda-beda. Jumlah pasien penderita penyakit infeksi saluran pernapasan akut (ISPA) di Kabupaten Kubu Raya pada tahun 2015 mencapai angka 34718 orang yang tercatat di 19 puskesmas yang tersebar di 9 kecamatan. Jumlah penderita ISPA, Hotspot, dan Luas Lahan Terbakar Kabupaten Kubu Raya tahun 2015 dapat dilihat pada tabel 3.

Berdasarkan Tabel 3, dilakukan analisis statistik dengan menggunakan Minitab 16 untuk uji korelasi dan uji regresi. Uji korelasi dilakukan untuk melihat hubungan antara jumlah hotspot, luas areal terbakar dengan jumlah pasien ISPA. Sementara uji regresi dilakukan untuk melihat pengaruh dan mendapatkan persamaan regresi dari kebakaran hutan dan lahan terhadap kejadian penyakit ISPA. Berikut adalah hasil korelasi antara ISPA, jumlah hotspot dan luas lahan terbakar.

\section{P-Value}

Dari hasil tersebut dapat dijelaskan bahwa antara jumlah pasien ISPA dengan jumlah Hotspot memiliki korelasi positif yang mempunyai hubungan sedang tetapi mendekati hubungan yang kuat $(r=0.507)$. Nilai korelasi antara jumlah pasien ISPA dengan luas lahan terbakar juga memiliki nilai korelasi positif yang mempunyai hubungan sedang $(r=0.377)$. Sementara untuk hubungan antara jumlah hotspot dengan luas areal

Tabel 3 Jumlah penderita ISPA, Hotspot, dan Luas Lahan Terbakar Kabupaten Kubu Raya tahun 2015

\begin{tabular}{lrrr}
\hline \multicolumn{1}{c}{ Kecamatan } & ISPA & Hotspot & $\begin{array}{c}\text { Luas } \\
\text { Terbakar } \\
\text { (Ha) }\end{array}$ \\
\hline $\begin{array}{l}\text { Sungai } \\
\text { Ambawang }\end{array}$ & 6420 & 11 & 663.78 \\
Kuala Mandor & 1603 & 8 & 22.29 \\
Sungai Raya & 11302 & 144 & 4248.28 \\
Sungai Kakap & 4610 & 6 & 4.18 \\
Rasau Jaya & 2360 & 34 & 618.39 \\
Teluk Pakedai & 1129 & 10 & 532.10 \\
Terentang & 2077 & 50 & 2272.85 \\
Kubu & 1810 & 78 & 1994.56 \\
Batu Ampar & 3407 & 127 & 5881.46 \\
\hline Jumlah & 34718 & 468 & 16238 \\
\hline
\end{tabular}


terbakar memiliki nilai korelasi positif yang mempunyai hubungan sangat kuat $(\mathrm{r}=0.938)$. Walaupun nilai korelasinya berbeda-beda, ada yang tinggi dan rendah tetapi nilai korelasinya masih positif. Hal ini dapat diartikan bahwa dengan memperhitungkan jumlah pasien penderita ISPA, masih ada korelasi positif antara jumlah hotspot dengan luas lahan terbakar. Sehingga, semakin tinggi jumlah hotspot dan semakin luas lahan terbakar, maka akan ada kecenderungan jumlah pasien ISPA semakin meningkat.

Nilai regresi yang didapat dari hasil analisis Minitab 16, dapat diperoleh sebagai berikut :

$\mathrm{r}^{2}($ koefisien determinasi $)=25.7 \%$ dengan persamaan garis :

$$
\mathrm{Y}=2240+31.1 \mathrm{X}
$$

Keterangan:

$\mathrm{Y}=$ Jumlah pasien ISPA

$\mathrm{X}=$ Jumlah hotspot

Jumlah pasien ISPA dipengaruhi $25.7 \%$ oleh jumlah hotspot dan $74.3 \%$ jumlah pasien ISPA dipengaruhi oleh faktor lainnya, seperti faktor cuaca dan iklim. Persamaan garis yang diperoleh tidak revlan diterapkan karena nilai uji R square kurang dari 50\%. Jika model persamaan yang diperoleh menghasilkan nilai koefisien determinasi yang rendah $\left(\mathrm{r}^{2}<50 \%\right)$, maka model persamaan yang dihasilkan tidak relevan untuk diterapkan.

Persamaan garis yang tidak relevan dapat dilihat dari data pada tabel 3. Kecamatan Batu Ampar, Kubu, dan Terentang yang memiliki jumlah hotspot dan luas lahan terbakar yang tinggi namun pasien ISPA tergolong rendah. Data tersebut yang mengurangi nilai koefisien determinasi karena jumlah pasien ISPA yang rendah tidak berbanding lurus dengan jumlah hotspot dan luas

Tabel 4 Nilai Korelasi antara Jumlah penderita ISPA, hotspot, dan luas lahan terbakar

\begin{tabular}{llc}
\hline & ISPA & Hotspot \\
\hline Hotspot & 0.507 & 1 \\
& 0.163 & 1 \\
Luas terbakar & 0.377 & 0.000 \\
(ha) & 0.938 & \\
& 0.318 & \\
\hline
\end{tabular}

Cell Contents: Pearson correlation

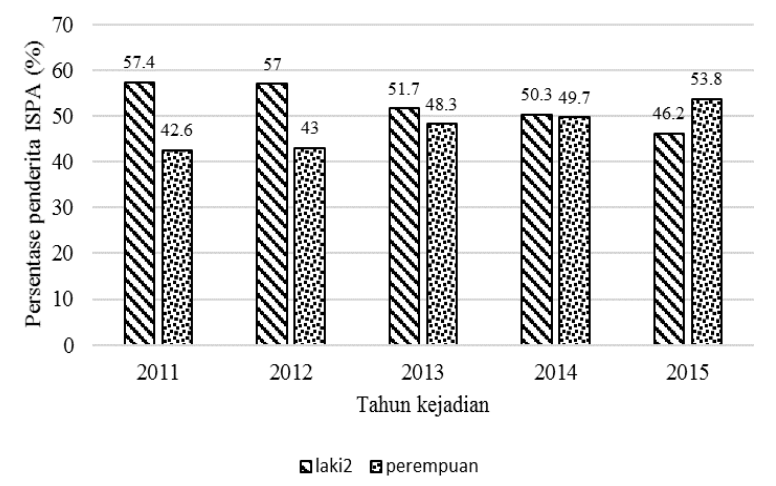

Gambar 3 Presentase Penderita ISPA berdasarkan jenis kelamin lahan terbakar yang tergolong tinggi. Sedangkan pada kecamatan Sungai Kakap dan kecamatan Sungai Ambawang memiliki jumlah hotspot dan luas lahan terbakar yang rendah namun pasien ISPA tergolong tinggi. Hal tersebut berkaitan dengan nilai korelasi antara jumlah pasien ISPA dengan hotspot dan luas kebakaran yang memiliki nilai korelasi sedang atau tidak kuat. Sedangkan nilai korelasi jumlah hotspot dengan luas lahan terbakar sangatlah berkaitan sangat erat.

Kecamatan yang memiliki jumlah pasien ISPA lebih sedikit daripada jumlah hotspot dan luas lahan terbakarnya seperti kecamatan Batu Ampar, Kubu, dan Terentang dapat disebabkan karena asap bergerak dan tidak selalu diam di atmosfir. Pergerakan asap juga dipengaruhi oleh arah angin, kecepatan angin dan kondisi atmosfir.

\section{Perbandingan Penderita Pasien ISPA Berdasarkan Jenis Kelamin}

Gambar 3 menunjukan persentase penderita ISPA berdasarkan jenis kelamin yang didominasi dengan pasien laki-laki pada tahun 2011-2014, sedangkan pada tahun 2015 pasien perempuan lebih banyak dibandingkan pasien laki-laki. Berdasarkan hasil penelitian Daroham dan Mutiatikum (2009), menunjukkan bahwa tidak terdapat perbedaan prevalensi, insiden maupun lama ISPA pada laki-laki dibandingkan dengan perempuan. Namun menurut beberapa penelitian kejadian ISPA lebih sering didapatkan pada anak laki-laki dibandingkan anak perempuan, terutama anak usia muda, dibawah 6 tahun. Dilihat dari jumlah penduduk di kabupaten Kubu Raya pun, jumlah penduduk laki-laki lebih banyak daripada jumlah penduduk perempuan.

Pasien laki-laki lebih banyak dibandingkan pasien perempuan dapat disebabkan oleh kebiasaan masyarakat atau pekerjaan masyarakat yang menuntut laki-laki lebih banyak beraktivitas diluar rumah walaupun sedang terjadi kabut asap. Masyarakat Kabupaten Kubu Raya yang sebagian besar berprofesi sebagai petani yang mengelola ladang dan kelapa sawit biasanya tetap melakukan aktivitas berladangnya, karena berladang merupakan mata pencaharian utama masyarakat di Kabupaten Kubu Raya. Beraktivitas di luar rumah pada saat terjadi kabut asap berpeluang lebih besar terkena penyakit Saluran Pernapasan.

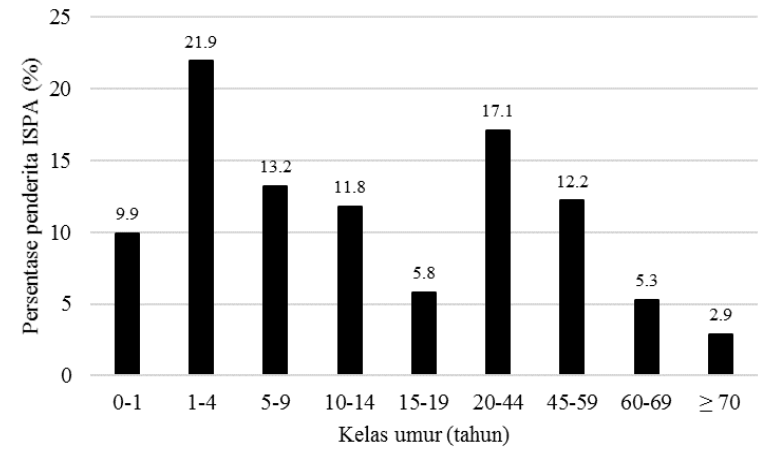

Gambar 4 Persentase jumlah penderita ISPA berdasarkan kelas umur 


\section{Perbandingan Penderita Pasien ISPA Berdasarkan Kelas Umur}

Persentase penderita ISPA berdasarkan kelas umur dapat dengan mudah dilihat pada gambar 4. Persentase pasien ISPA terbanyak terjadi pada kelas umur 1 - 4 tahun atau masih tergolong balita. Hal ini disebabkan karena perbedaan kemampuan kekebalan tubuh terhadap agen penyakit. Bayi dan anak-anak lebih lemah dari orang dewasa. Infeksi saluran pernapasan bagian atas terutama yang disebabkan oleh virus, sering terjadi pada semua golongan umur, tetapi ISPA yang berlanjut menjadi Pneumoni sering terjadi pada anak kecil terutama apabila terdapat gizi kurang dan dikombinasi dengan keadaan lingkungan yang tidak hygiene (Sundari et al 2014).

Kelas umur 20-44 tahun merupakan kelas umur yang memiliki persentase tertinggi setelah kelas umur 1 - 4 tahun yaitu sebesar $17.1 \%$. Daroham dan Mutiatikum (2009) yang menyebutkan bahwa yang berusia di atas 15 tahun lebih banyak menderita sakit ISPA $(61.83 \%)$ dibandingkan dengan yang berusia di bawah 15 tahun (38.17 \%). Kelas unur 20-44 tahun merupakan golongan umur produktif bekerja dan memiliki aktivitas yang tergolong padat. Oleh karena itu, kelas umur 20-44 tahun rentan terkena penyakit saluran pernapasan karena lebih banyak beraktivitas di luar rumah.

\section{SIMPULAN DAN SARAN}

\section{Simpulan}

Jumlah pasien ISPA dengan jumlah Hotspot memiliki korelasi positif yang mempunyai hubungan sedang tetapi mendekati hubungan yang kuat ( $\mathrm{r}=$ 0.507). Nilai korelasi antara jumlah pasien ISPA dengan luas lahan terbakar juga memiliki nilai korelasi positif yang mempunyai hubungan sedang $(\mathrm{r}=0.377)$, sedangkan untuk hubungan antara jumlah hotspot dengan luas areal terbakar memiliki nilai korelasi positif yang mempunyai hubungan sangat kuat $(r=0.938)$. Hal ini dapat diartikan bahwa dengan memperhitungkan jumlah pasien penderita ISPA, masih ada korelasi positif antara jumlah hotspot dengan luas lahan terbakar walaupun hubungannya tidak kuat. Hasil uji R-square persamaan regresi pasien ISPA dengan jumlah hotspot $\mathrm{Y}=2240+31.1 \mathrm{X}$ tidak relevan digunakan karena nilai uji R-square kurang dari $50 \%$ yaitu hanya sebesar $25.7 \%$. Presentase penderita ISPA berdasarkan jenis kelamin yang didominasi dengan pasien laki-laki pada tahun 2011-2014, sedangkan pada tahun 2015 pasien perempuan lebih banyak dibandingkan pasien laki-laki. kelas umur terbanyak pada pasien ISPA Kubu Raya adalah kelas umur 1-4 tahun (balita).

\section{Saran}

Menghimbau masyarakat agar tidak beraktivitas di luar rumah apabila terjadi kabut asap dari kebakaran hutan dan lahan di daerahnya. Data jumlah pasien ISPA, sebaiknya mengambil data ke puskesmas yang memiliki data lengkap dan lebih rinci. Perlu dilakukan penelitian lebih lanjut lagi mengenai dampak dari kebakaran hutan dan lahan terhadap kesehatan manusia, yang dapat dilihat dari data pencemaran udara, PM10, dan unsur cuaca lainnya.

\section{DAFTAR PUSTAKA}

Chahaya I. 2003. Pengendalian Pencemaran Udara Melalui Penanganan Emisi Gas Buang Kendaraan Bermotor. Medan (ID): Fakultas Kesehatan Masyarakat Universitas Sumatra Utara.

Daroham, Mutiatikum. 2009. Penyakit ISPA hasil riskesdas Indonesia. Buletin Penelitian Kesehatan Supplement. Puslitbang biomedis dan farmasi.

Faisal F, Yunus F, Harahap F. 2012. Dampak Asap Kebakaran Hutan pada Pernapasan. Cermin Dunia Kedokteran edisi 189 (39);31-35.

Mattjik AA, Sumerrajaya M. 2013. Perancangan Percobaan Dengan Aplikasi SAS Dan Minitab Jilid I. Bogor (ID). IPB Press.

Nasution AZ, Mubarak, Zulkifli. 2013. Studi Emisi $\mathrm{CO}_{2}$ Akibat Kebakaran Hutan di Provinsi Riau (Studi Kasus Kabupaten Siak). Jurnal Bumi Lestari. 13: 26-36.

Saharjo BH, Syaufina L. 2015. Kebakaran Hutan dan Lahan Gambut (Presentasi Power Point). IPN Toolbox. Tema C Subtema C3. www.cifor.org/ipntoolbox

Sundari S, Pratiwi, Khairudin. 2014. Perilaku Tidak Sehat Ibu yang Menjadi Faktor Resiko Terjadinya ISPA Pneumonia pada Balita. Jurnal Pendidikan Sains vol.2 hlm.141-147. Malang (ID). Politeknik Kesehatan Kementrian Kesehatan Malang.

Purbowaseso B. 2004. Pengendalian Kebakaran Hutan. Jakarta (ID): Rineka Cipta.

Sarwono J. 2013. 12 Jurus Ampuh SPSS untuk Riset Skripsi. Jakarta (ID). Elexmedia Komputindo Kompas Gramedia.

Solichin. 2005. Panduan Pengumpulan Informasi Kebakaran Hutan dan Lahan melalui Internet. Palembang (ID): South Sumatra Forest Fire Management Project.

Syaufina L. 2008. Kebakaran Hutan dan Lahan di Indonesia. Malang (ID). Bayumedia Publishing.

Tristiyenny P. 2003. Dampak Kesehatan Masyarakat dan Estimasi Kerugian Ekonomi Akibat Kebakaran Hutan dan Lahan di Kabupaten Bengkalis Tahun 2002. [tesis]. Jakarta (ID): Fakultas Kesehatan Masyarakat Universitas Indonesia.

Walpole ER. 1993. Pengantar Statistika Edisi 3. Bambang Sumantri, penerjemah. Jakarta (ID): Gramedia. 